Mikołaj Tarkowski

Uniwersytet Warmińsko-Mazurski w Olsztynie e-mail: mikolaj.tarkowski@uwm.edu.pl telefon: +48 895246491

DOI: $10.15290 / \mathrm{mhi} .2016 .15 .02 .18$

\title{
Prawa autorskie jako element kultury prawnej. Ochrona własności literackiej, artystycznej i muzycznej w Imperium Rosyjskim w poglądach Włodzimierza Spasowicza
}

\begin{abstract}
SUMMARY
Copyright as a component of legal culture. Protection of copyright in the field of literature, music and visual arts in the Russian Empire - the view of Włodzimierz Spasowicz
\end{abstract}

The article is devoted to the views of Włodzimierz Spasowicz on copyright of the Russian Empire in the nineteenth century. The issue of copyright in literature, music and visual arts were characterized on the basis of civil law and criminal law. Włodzimierz Spasowicz represented interesting opinion on the international aspect of copyright protection. The polemic - between Włodzimierz Spasowicz and Pierre Joseph Proudhon - on the essence of copyright was equally important.

Key words: Włodzimierz Spasowicz, copyright, copyright infringement, Russian Empire.

Słowa kluczowe: Włodzimierz Spasowicz, prawo autorskie, naruszenie praw autorskich, Imperium Rosyjskie.

Włodzimierz Spasowicz urodził się 16 stycznia 1829 r. w Rzeczycy w guberni mińskiej, jako syn lekarza Daniela i Teofilii z Kreutzów. Zmarł 26 października 1906 r. w Warszawie. Był wyznania prawosławnego, jednakże w domu zaszczepiono w nim polskie wychowanie. Ukończył gimnazjum w Mińsku. Studia prawnicze rozpoczął w 1845 r. na Uniwersytecie w Sankt Petersburgu. Równolegle uczestniczył w zajęciach organizowanych w ramach Polskich Kursów Prawnych, na których wykłady prowadzili: Antoni Czajkowski i Romuald Hube. W trakcie studiów utrzymywał kontakty z członkami umiarkowanego środowiska skupionego wokół Jakuba Gieysztora, ale również stykał się z działaczami

J. Bardach, Spasowicz Włodzimierz, [w:] Polski Słownik Biograficzny, red. A. Romanowski, t. XLI/1, z. 168, Warszawa - Kraków 2002, s. 45. 
radykalnymi, takimi jak: Zygmunt Sierakowski, czy też Baltazar Kalinowski. W tym samym czasie Włodzimierz Spasowicz pozostawał pod silnym wpływem polskiej literatury romantycznej, zwłaszcza mesjanizmu, którego źródłem była twórczość Zygmunta Krasińskiego². Późniejszy krytyk i historyk literatury od najmłodszych lat gimnazjalnych poznawał utwory literackie rosyjskich pisarzy, w tym Aleksandra Puszkina, Michaiła Lermontowa i Nikołaja Gogola 3 .

Włodzimierz Spasowicz ukończył studia prawnicze w 1849, broniąc pracę poświęconą dziejom Konfederacji Szwajcarskiej ${ }^{4}$. Kolejnym istotnym punktem w rozwoju kariery naukowej było napisanie pod kierunkiem Ignacego Iwanowskiego studium magisterskiego (odpowiednika doktoratu) z zakresu prawa międzynarodowego publicznego zatytułowanego O prawach neutralnej bandery i neutralnego ładunku (Sankt Petersburg 1850)5. Jednocześnie autor pozostawał bardzo aktywny na polu publicystycznym, drukując artykuły w wydawanym w latach 1849-1851 w Wilnie „Pamiętniku Naukowo-Literackim”6. W 1857 r. Włodzimierz Spasowicz na podstawie opracowania opublikowanego w stolicy Imperium Rosyjskiego, pod tytułem O stosunkach majątkowych między małżonkami wedle dawnego prawa polskiego uzyskał veniam legendi na Uniwersytecie w Sankt Petersburgu, rozpoczynając jednocześnie pracę w Katedrze Praw Cywilnych Królestwa Polskiego ${ }^{7}$. W grudniu 1857 r. przeszedł do Katedry Prawa Karnego ${ }^{8}$. Pracował w niej do 1861 r., kiedy musiał zrezygnować z pracy na uczelni na skutek opowiedzenia się za profesorami petersburskiej uczelni, którzy wcześniej wsparli studenckie grono protestujące przeciw postanowieniom rosyjskiego Ministerstwa Oświaty. Tymczasowym miejscem pracy Spasowicza stało się Liceum Prawnicze, a następnie, z racji przejściowego zamknięcia Uniwersytetu w Sankt Petersburgu, wykładał on również na „wolnym uniwersytecie”.

Włodzimierz Spasowicz uzyskał w grudniu 1863 r. stopień doktora (w rozumieniu carskiego systemu szkolnictwa wyższego) na podstawie pracy zatytułowanej Podręcznik prawa karnego. Opracowanie zyskało przychylność liberalnych, petersburskich kręgów. Jednak jego oponentami stali się profesorowie prawa karnego działający na Uniwersytecie w Moskwie. Krytyka okazała się na tyle silna, iż Aleksander II nakazał utworzyć specjalną komisję, która następnie

2 D. Szpoper, Wstęp, [w:] W. Spasowicz, Liberalizm i narodowość. Wybór pism, red. M. Jaskólski, J. Kloczkowski, M. Kuniński, R. Legutko, J. M. Majchrowski, T. Merta, B. Szlachta, Kraków 2010, s. VIII.

3 E. Sławęcka, Włodzimierz Spasowicz jako krytyk literatury rosyjskiej, Wrocław, Warszawa, Kraków 1969, s. 11.

4 J. Bardach, Spasowicz Włodzimierz... , s. 45.

5 Idem, Włodzimierz Spasowicz (1829-1906), [w:] W obiektywie nauki i w lustrze pamięci (o uczonych, pisarzach i politykach XIX wieku), red. W. Sudnik, Warszawa 2004, s. 302.

$6 \quad$ Włodzimierz Spasowicz w 1859 r. założył wraz z Józefatem Ohryzką, Edwardem Żeligowskim i Zygmuntem Sierakowskim wydawane w Sankt Petersburgu polskie czasopismo „Słowo”. Zob. D. Szpoper, Pomiędzy caratem a snem o Rzeczypospolitej. Myśl polityczna i działalność konserwatystów polskich w guberniach zachodnich Cesarstwa Rosyjskiego w latach 1855-11862, Gdańsk 2003, s. 63.

7 M. Jankowski, Być liberałem w czasie trudnym. Rzecz o Włodzimierzu Spasowiczu, Łódź 1996, s. 30-40.

$8 \quad$ J. Kulczycka-Saloni, Włodzimierz Spasowicz. Zarys monograficzny, Wrocław - Warszawa - Kraków Gdańsk 1975, s. 21. 
zarzucając szerzenie idei zagrażających porządkowi publicznemu, doprowadziła w 1864 r. do odsunięcia uczonego od wykonywania służby publicznej9 .

Włodzimierz Spasowicz, po utracie stanowiska uniwersyteckiego, zmuszony trudną sytuacją materialną, poszukiwał nowych form aktywności i zarobkowania. W maju 1866 roku wstąpił w szeregi utworzonej na fali reform sądowych Aleksandra II adwokatury przysięgłej w Sankt Petersburgu. Niezależnie od aktywności adwokackiej, która z czasem przyniosła mu rozgłos i prominentną pozycję, także w kręgach władzy, Włodzimierz Spasowicz działał na niwie literackiej. W tym okresie opublikował m.in. Historię literatury polskiej (w języku rosyjskim książka ukazała się w 1865 r.). Zamieszczał także recenzje i szkice literackie w czasopiśmie „Sankt Petersburskie Wiadomości”10. W 1866 r. rozpoczął współprace z dziennikiem „Wiestnik Jewropy”11. Poświęcał się także pracy redakcyjnej na rzecz, założonego w 1876 r., warszawskiego czasopisma naukowo-literackiego „Ateneum”"12.

W jednym z artykułów opublikowanych w 1888 roku na łamach tego periodyku, jak się wydaje z uwagi na obowiązującą w Imperium Rosyjskim normę ustanawiającą pięćdziesięcioletni termin ochrony praw literackich, podkreślał, iż: „Od dawnego czasu zajmowała mnie myśl zaczęcia studiów porównawczych nad bajronistami od zestawienia dwóch par pierwszorzędnych poetów z dwu rasowo spokrewnionych narodowości polskiej i rosyjskiej, pisarzy należących do jednej i tejże samej epoki romantyzmu: Mickiewicza i Puszkina, Lermontowa i Słowackiego. Spełniłem dotąd tylko połowę zadania, wykończyłem tylko część pracy tyczącą rosyjskiej literatury i mogę obecnie podać owoce moich spostrzeżeń, wydobyte z dzieł Puszkina, którego 50-letnią rocznicę zgonu obchodzono w styczniu roku zeszłego, i Lermontowa, którego również 50-letnią rocznicę obchodzić będziemy, jeżeli dożyjemy, 15 lipca 1891 roku"13.

Z kolei wspólnie z Erazem Piltzem petersburski prawnik założył wydawany w latach 1882-1907 tygodnik polityczno-literacki „Kraj”14. W pierwszym numerze czasopisma redakcja zaznaczyła, iż jednym z celów działalności tego periodyku był przegląd „prasy i literatury rosyjskiej, żeby dać czytelnikom [...] możliwość rozejrzenia się we wszystkich przejawach życia społecznego, politycznego i umysłowego Rosji [...]"15. Włodzimierz Spasowicz zagadnieniom literackim poświęcił dużo miejsca na kartach wydawanych w latach 1892-1903 Pism. Wśród opublikowanych w ramach tego opracowania artykułów znajdowały się również prace poświęcone problematyce ochrony praw autorskich.

J. Bardach, Włodzimierz Spasowicz (1829-1906)... , s. 305.

10 W języku polskim studium ukazało się po raz pierwszy w $1882 \mathrm{r}$. W 1885 r. poprawił i uzupełnił tę pozycję Antoni Gustaw Bem; zob.: M. Jankowski, op. cit., s. 77. Zob. też: ibidem, s. 306.

$11 \quad$ E. Sławęcka, op. cit., s. 20.

12 D. Szpoper, Wstęp... , s. XVIII.

13 Cyt. za: W. Spasowicz, Puszkin i Lermontow jako Bajroniści, „Ateneum” 1888, t. 1, z. 3, s. 454-455.

14 Z. Kmiecik, „Kraj” za czasów redaktorstwa Erazma Piltza, Warszawa 1969, s. 128.

15 Cyt. za: „Kraj” 4(16) lipca 1882, nr 1, s. 1. 
W tym miejscu warto wymienić następujące teksty: Rzecz o tak zwanej „własności literackiej" (t. 4, 1892) ${ }^{16}$ oraz O prawie własności w literaturze (t. 4, 1892) ${ }^{17}$.

Włodzimierz Spasowicz występował często w roli prelegenta referatów poświęconych problematyce literackiej. Uczestniczył w zjazdach i sympozjach w Krakowie, Warszawie i Lwowie. Od 1873 r. był członkiem Akademii Umiejętności w Krakowie. Istotnym wydarzeniem w warszawskim środowisku intelektualnym było założenie w 1906 r., przy współudziale Spasowicza, Warszawskiego Towarzystwa Przyjaciół Nauk.

Przez całe aktywne życie angażował się on również w prace organizacji i stowarzyszeń naukowych i literackich działających w stolicy Imperium Rosyjskiego, a także w Moskwie. Był bowiem członkiem Związku Pisarzy Rosyjskich (zasiadał w komisji prawniczej, pełnił funkcję sędziego honorowego). W 1899 roku Włodzimierz Spasowicz wziął udział w uroczystości, zorganizowanej przez tę organizację, związaną z obchodami jubileuszu stulecia urodzin Adama Mickiewicza. Ważnym wydarzeniem w petersburskim środowisku literackim było także upamiętnienie setnych urodzin Aleksandra Puszkina. Jubileusz odbył się 23 maja 1899 r. w redakcji „Kraju”. Uroczystościom przewodniczył Włodzimierz Sapasowicz ${ }^{18}$.

Spoglądając na biogram oraz dorobek naukowy Włodzimierza Spasowicza, osoby obracającej się w rosyjskich i polskich kręgach literackich, naturalnym wydaje się fakt, iż petersburski adwokat, przejawiał zainteresowanie instytucjami prawa autorskiego obowiązującego w XIX w. w Cesarstwie Rosyjskim. Do czasu wprowadzenia w latach dwudziestych XIX w. pierwszych aktów prawnych regulujących prawa autorskie osób prywatnych, w Rosji obowiązywała zasada, zgodnie z którą ochronie praw autorskich podlegały tylko osoby prawne ${ }^{19}$, a zatem „pewne założone i utrzymywane przez rząd uczone korporacje”. Obowiązujące w tym zakresie normy, które charakteryzowały się swego rodzaju wyłącznością posiadania praw autorskich przez wybrane instytucje publiczne, miały swe źródło w ukazie z 26 września 1732 r. Ukaz zabraniający przywozu na teren Rosji przedrukowanych wydań kalendarzy (zwanych także wiadomostiami), które były pierwotnie publikowane przez drukarnię Carskiej Akademii Nauk, został wprowadzony na skutek skarg płynących z samej Akademii. Władze tej instytucji spostrzegły bowiem, iż część publikacji akademickich była wydawana przez prywatne osoby i oficyny na terenie Niemiec. Innym przejawem tendencji monopolistycznej były ukazy z 1 listopada 1784 i 5 sierpnia 1786 r.

16 Pierwsze wydanie tej pracy miało miejsce w 1864 roku; zob.: Prawo autorskie. Ustawa o prawie autorskim z r. 1926 w brzmieniu jednolitego tekstu z 1935 r. z objaśnieniami i dodaniem Konwencji berneńskiej, red. G. Groeger, Warszawa 1937, s 63.

17 J. Bardach, Włodzimierz Spasowicz (1829-1906)... , s. 312.

18 W skład prezydium jubileuszowego sympozjum wchodzili także: wiceprezydent Cesarskiej Akademii Nauk w Sankt Petersburgu Leonid Majkow oraz prezes Towarzystwa Historycznego Mikołaj Kariejew. Zob.: J., Uczta jubileuszowa, „Kraj” 16 maja (9 czerwca) 1899, nr 22, s. 8; zob. też: J. Bardach, Włodzimierz Spasowicz (1829-1906)... , 318; E. Sławęcka, op. cit., s. 21.

19 L. Górnicki, Rozwój idei praw autorskich: od starożytności do II wojny światowej, Wrocław 2013, s. 143. 
Treść norm w nich zawartych stanowiła, iż komisja szkół narodowych dysponowała uprawnieniem wyłącznego przedrukowywania książek oddawanych do użytku w szkołach narodowych ${ }^{20}$.

Sytuacja prawna osób prywatnych zaczęła się z czasem zmieniać. Rozporządzenie z dnia 22 kwietnia 1828 r. O prawach twórców i wydawców usankcjonowało prawa autorskie osób prywatnych w Imperium Rosyjskim. Stanowiło ono jednocześnie część ustawy o cenzurze z tego samego roku ${ }^{21}$. W objaśnieniach do niej, wydanych w styczniu 1830 r. (na mocy Najwyżej zatwierdzonego zdania Rady Państwa), prawa autorskie określono terminem własności literackiej $^{22}$. W późniejszym czasie katalog praw autorskich został rozszerzony, gdyż wprowadzono w życie w latach czterdziestych XIX wieku rozporządzenia regulujące „własność artystyczną” (sztuki plastyczne) oraz „własność muzyczną”. W drugiej połowie XIX w. do systemu praw autorskich, w tym ich ochrony, wprowadzono jeszcze jedną bardzo istotną zmianę. Dotychczasowy zasadniczy dwudziestopięcioletni okres trwania praw autorskich został, w wyniku ustanowienia Najwyżej zatwierdzonego zdania Rady Państwa z 15 kwietnia 1857 r., wydłużony do 50 lat ${ }^{23}$.

Analizując podstawowe zjawiska społeczne petersburski adwokat podkreślił, iż naturalnie problematyka praw autorskich do czasu wynalezienia druku nie mogła stanowić przedmiotu dyskusji i badań w zachodnioeuropejskim kręgu kulturowym. Dodatkowo upowszechnienie się druku nie skutkowało automatycznie powstaniem koncepcji ochrony praw autorskich. Spasowicz pisał w związku z tym: „Wydawca skąpił na autorskie honorarium, wiedząc że niebawem to samo dzieło będzie przedrukowane i puszczone w świat po niskiej cenie przez spekulanta, który nie autorowi zapłacił”. Dodawał przy tym, iż: „Opinia publiczna postępiała nieprawne przedruki; lecz sądy nie dawały obrony autorom i wydawcom, a to dlatego, że szkoda wypływająca z kontrefakcji nie dała się podciągnąć pod żadną z form cywilnych lub karnych ówczesnego obowiązującego prawodawstwa, czy to rzymskiego lub kanonicznego, czy też zwyczajowego". Uzupełniając niejako ten pogląd warto podkreślić, iż pierwsze próby uregulowania praw autorskich w Cesarstwie Rosyjskim, nie zaistniałby bez rozwoju w XVIII w. tak samego języka rosyjskiego (który zaczął wypierać z powszechnego obiegu kulturowego język cerkiewnosłowiański), jak również ruchu drukarskiego i wydawniczego ${ }^{24}$.

\footnotetext{
20 W pierwszej wersji książka opublikowana została w 1865 r. w Sankt Petersburgu (ros. tytuł: Prava avtorskije i kontrafakcija). Zob.: W. Spasowicz, Prawa autorskie i kontrefakcja, Warszawa 1874, s. 10.

$21 \quad$ Ibidem, s. 10.

22 L. Górnicki, op. cit., 143.

23 W. Spasowicz, Prawa autorskie i kontrefakcja... , s. 10-11.

24 Dane, mówiące o 600 książkach wydanych za panowania Piotra I, 2000 opublikowanych w latach 1725-1775 oraz 7500 wydanych w ostatnim ćwierćwieczu XVIII w. Zob.: W. Zajączkowski, Rosja i narody. Ósmy kontynent. Szkic dziejózw Euroazji, Warszawa 2015, s. 94.
} 
Zdaniem Włodzimierza Spasowicza podstawowe pojęcie dla praw autorskich w Imperium Rosyjskim, jakim była „własność literacka” było niepoprawne. Określenie to, posiadające wąski zakres podmiotowy, powodowało „wielki zamęt w pojęciach", a także dezorientowało sądy, które stawały przed zadaniem rozstrzygania spraw o naruszenie praw autorskich (kontrefakcja) autorów i wydawców. Ustawa o cenzurze wraz z załączonymi do niej objaśnieniami regulowała bowiem, nie tylko prawa autorów, ale kształtowała także stosunki pomiędzy autorami i wydawcami oraz zawierała essentiale negoti umowy wydawniczej. Włodzimierz Spasowicz, mając na uwadze poszczególne uprawnienia stron umowy wydawniczejej, zauważył, iż jej treść nie powinna być uregulowana przepisami ustawy o cenzurze z 1828 r., lecz przepisy te powinny wejść bezpośrednio w skład części 1, tomu 10 Zbioru Praw Cesarstwa Rosyjskiego z 1832 r. ${ }^{26}$ Dodatkowo Spasowicz podkreślił wyraźnie na kanwie analizy ustaleń międzynarodowego Kongresu prawa autorskiego w Brukseli z 1858 r., iż w Imperium Rosyjskim prawo własności literackiej, które nazwę swą zawdzięcza leksyce francuskiej (propriété littéraire), obejmowało nie tylko pisarzy, ale także inne osoby zajmujące się działalnością twórczą, w tym plastyczną, fotograficzną, naukową, czy też muzyczną. Znawca prawa autorskiego pisał: „Logika nie pozwalała się łudzić [...] wskazując, że wyrażenie «własność literacka» jest tylko metaforą, że rzecz sama posiada [...] wyłączne cechy, że gdyby nawet istotną własność tutaj zaprowadzono, stanęłaby ona niebawem w kolizji z niemniej ważnymi prawami dobra publicznego" ${ }^{\prime 27}$.

W poglądach petersburskiego adwokata na pierwszy plan wysuwał się charakter praw autorskich. Analizując to zagadnienie uznał, iż prawa autora do utworu można podzielić na osobiste i majątkowe. Taki podział wywodził się z dychotomicznej typologii „prywatnych praw pojedynczych osób”. Biorąc pod uwagę takie założenie Spasowicz podkreślał istnienie osobistej więzi pomiędzy twórcą a dziełem. Bezwzględny charakter praw autorskich wyrażać się miał w zasadzie, iż np. książka nie mogła być wydana lub przedrukowana przez kogokolwiek bez zgody autora. Jednocześnie petersburski prawnik dodawał, wskazując na majątkowy charakter prawa własności literackiej, że "gdyby prawo autora miało jedynie tę podstawę [prawa o charakterze osobistym], nie mogłoby ono trwać dłużej niż sam autor". Spasowicz uważał jednocześnie, iż prawodawstwa powinny odróżniać utwory literackie od nieliterackich. Do tych ostatnich zaliczył materiały, opracowania, pamiętniki, które mogą posłużyć jako źródła historyczne. „Rzeczy nieliterackie” powinny stać się, z chwilą śmierci autora, dobrem powszechnym. Taką koncepcję argumentował następująco:

25 Szerzej o uprawnieniach stron umowy wydawniczej (autora i wydawcy) szerzej zob.: L. Górnicki, op. cit., s. 144 .

26 W. Spasowicz, Rzecz o tak zwanej własności literackiej, [w:] Pisma, t. 4, Sankt Petersburg 1892, s. 91-92 por. Vysoczajszie utvierżdiennyj 20 marta 1911 goda zakon' ob avtorskom' pravie, [w:] Svod Zakonov Rossijskoj Imperii, t. X, cz. I, Sankt Peterburg 1912, s. 201-202.

27 Cyt. za: idem, Prawa autorskie i kontrefakcja... , s. 14. 
„Zakaz wydawania materiałów, które mają znaczenie nie same przez się, lecz w związku z historyczną osobą, jako pozostałe po niej pamiątki, krępuje historię, nikomu nie będąc właściwie pożytecznym"28.

Generalna ocena prezentowana przez Włodzimierza Spasowicza na temat prawa własności literackiej w Imperium Rosyjskim była w zasadzie negatywna. Za przestarzałe rozwiązania uznał on bowiem, te które wynikały z przepisów obejmujących ochroną prawną wszelkie mowy publiczne, których nie można było swobodnie przedrukowywać i publikować. Krytyce poddał również stan prawny, w którym z jednej strony w 1864 roku - na fali reform sądowych Aleksandra II - dozwolono drukowania relacji i protokołów z publicznych posiedzeń sądów, z drugiej zaś rozpowszechnianie mów ze zgromadzeń publicznych nie miało wyraźnej prawodawczej sankcji. W opinii Spasowicza anachronizmem, bardzo zresztą uciążliwym, był bezwzględny zakaz ogłaszania drukiem listów i innych osobistych dokumentów, które nie posiadały klauzuli umożliwiającej publiczne udostępnianie. Zgodę na upublicznienie musiał wydać zarówno autor, jak również adresat korespondencji. Spasowicz uważał, iż do rozciągnięcia ochrony na takie wartości, jak honor, czy też dobre imię zmarłego autora, wystarczyłoby obowiązywanie przepisów zakazujących przestępstwa dyfamacji - zniesławienia. Natomiast do katalogu dobrze ocenianych przez Włodzimierza Spasowicza koncepcji zaliczyć można tę umożliwiającą, na zasadzie dużej wolności, przekłady dzieł zagranicznych na język rosyjski. Proces taki sprawił, że w Imperium Rosyjskim „rozwinęła się i rozkwitła niezmiernie bogata i rozmaita literatura przekładowa, której pozazdrościć mogą inne najbardziej ucywilizowane kraje". Dodać jednak należy, iż według petersburskiego adwokata, daleko posunięta w tej mierze wolność, nie mogła zachęcać do naruszania praw autorskich zagranicznych twórców ${ }^{29}$.

Krytyka ze strony Włodzimierza Spasowicza skoncentrowała się nie tylko na wadliwej konstrukcji norm prawa własności literackiej, artystycznej i muzycznej rozpatrywanych na gruncie prawa cywilnego. Negatywne poglądy przeważały również $\mathrm{w}$ analizach rozwiązań prawnych w oparciu o system prawa karnego. Petersburski adwokat zwracał uwagę, że ochrona karnoprawna własności literackiej jest w Imperium Rosyjskim fikcyjna. W praktyce śledczy i sędziowie w sprawach o kontrefakcje przed rozpoznaniem oskarżenia, zmuszali strony do udowodnienia posiadania prawa autorskich do utworu na gruncie procesu cywilnego. Zdaniem Włodzimierza Spasowicza, udowodnienie swoich uprawnień nie gwarantowało sprawiedliwego wyroku w procesie karnym. Sądy, które miały do dyspozycji katalog bardzo surowych kar za popełnienie plagiatu, często uniewinniały oskarżonych, gdyż kontrefakcja mogła być popełniona wyłącznie wskutek złego zamiaru. Nieostrożne przedrukowanie cudzego dzieła nie było zatem penalizowane. Włodzimierz Spasowicz za trudne do wyegzekwowania

$28 \quad$ Cyt. za: idem, Rzecz o tak zwanej własności literackiej... , s. 76-77.

29 Cyt. za: ibidem, s. 93. 
uznał również przepisy ustawy o cenzurze z 1828 r. regulujące odpowiedzialność cywilnoprawną za naruszenie praw autorskich ${ }^{30}$. Nieprecyzyjne w tym zakresie przepisy stanowiły, iż sumę odszkodowania stanowił iloczyn z liczby opublikowanych egzemplarzy, pomnożonej przez różnicę ceny handlowej i ceny, którą uzyskał naruszający prawa autorskie ${ }^{31}$. Spasowicz dodawał, jednocześnie, iż „zmówiwszy się z drukarzem, kotrefaktor może z łatwością ukryć rzeczywistą cyfrę egzemplarzy przedruku". Petersburskiemu prawnikowi, jako nieskutecznie działające instytucje ochrony praw autorskich, jawiły się także komitety cenzury ${ }^{32}$.

Niezadowalający stan ochrony praw autorskich w Cesarstwie Rosyjskim skłonił Włodzimierza Spasowicza do poszukiwania rozwiązań naprawczych. Zgodnie z przyjętymi przez niego koncepcjami, ustawa o cenzurze z 1828 r., a także pozostałe akty prawne $z$ dziedziny prawa autorskiego powinny zostać zniesione. Nowe przepisy i normy miały być konstruowane przy współudziale zainteresowanych osób: pisarzy, księgarzy, wydawców, muzyków i artystów. Kary za naruszenie praw autorskich miały mieć wyłącznie charakter pieniężny. Włodzimierz Spasowicz opowiadał się za skróceniem, wprowadzonego w 1857 r., pięćdziesięcioletniego okresu trwania praw autorskich. Proponował ponowne wprowadzenie okresu dwudziestopięcioletniego ${ }^{33}$. Jego zdaniem pilną potrzebą było wprowadzenie norm zezwalających na przedrukowywanie źródeł informacji, w tym materiałów „odnoszących się nawet do najświeższej przeszłości”. Warte uwagi z pewnością są poglądy, zgodnie z którymi Spasowicz nie widział konieczności w zmienianiu prawidłowo dotychczas funkcjonujących instytucji prawa własności literackiej, w tym np. uwolnienia praw autorskich od egzekucji za długi ${ }^{34}$.

Petersburski znawca prawa autorskiego zajmował się również instytucjami ochrony własności intelektualnej na gruncie traktatów międzynarodowych. W tej mierze jego opinie zostały wyrażone w opracowaniach, które poświęcił Konwencji berneńskiej o ochronie dzieł literackich i artystycznych z 1886 r. ${ }^{35}$ Główną przyczyną, z powodu której Cesarstwo Rosyjskie, obok innych państw

Ibidem, s. 94 .

L. Górnicki, op. cit., s. 144.

W. Spasowicz, Rzecz o tak zwanej własności literackiej... , s. 94.

33 Włodzimierz Spasowicz w ten sposób argumentował konieczność skrócenia okresu ochrony praw autorskich: „Z dwu wielkich pisarzy rosyjskich XIX wieku, którzy pomarli na 11 lat jeden po drugim (1826-1837) [Nikołaja] Karamzina i [Aleksnadra] Puszkina, dzieła pierwszego nie są już poczytne, nikt ich nie reprodukuje, co stanowi najlepszy dowód, że nie potrzebują one wcale obrony przedruku. Co się zaś tyczy drugiego autora, prawo 1857 r. sprawiło, że nie posiadamy do dziś dnia taniego dobrego wydania dzieł [...] wieszcza". Zob. cyt. za: ibidem, s. 96.

$34 \quad$ Ibidem, s. 96-97.

35 O Konwencji berneńskiej zob.: Polska ustawa o prawie autorskim i Konwencja berneńska, red. F. Zoll, Warszawa 1926, s. 155, 157-165. 
takich, jak: Stany Zjednoczone Ameryki, Austro-Węgry ${ }^{36}$, nie podpisało tego traktatu były obowiązujące $\mathrm{w}$ Imperium przepisy dotyczące dokonywania tłumaczeń książek. Włodzimierz Spasowicz przewidywał, że rosyjskie władze nieprędko zdecydują się na zmianę prawodawstwa w tej dziedzinie. Aprobując treść postanowień konwencji, pisał: „Publiczność rosyjska wyzyskiwała dotąd wszystkie literatury europejskie, biorąc zewsząd swój pokarm, nic nikomu nie płacąc, nie może więc oswoić się z myślą o tamach, trudnościach, zwłokach, opłatach" $^{\prime 37}$.

Włodzimierz Spasowicz prowadził także polemikę z Pierre'em Josephem Proudhonem, krytykując go za „sofistyczną" postawę, którą przyjmował w dyskusjach na temat praw autorskich. Petersburski prawnik zauważył, iż w wydanym w 1862 r. dziele zatytułowanym O literackich majoratach, Proudhon nie przekreślił co prawda sensu własności literackiej jako takiej, lecz udowadniał, że praw autorskich nie można wyprowadzić z istoty i pojęcia dzieł sztuki. Włodzimierz Spasowicz nie zgadzał się w szczególności z zabiegiem, który dla uzasadnienia swoich racji wykonywał Proudhon, polegającym na utożsamianiu utwo$\mathrm{ru}$ artystycznego $\mathrm{z}$ produktem uzyskiwanym $\mathrm{w}$ procesie produkcyjnym. $\mathrm{W}$ tej koncepcji, autor utworu literackiego czerpał treść swego dzieła z różnych źródeł (pojęć, motywów, obrazów). Źródła te miały odpowiadać sklasyfikowanym w ekonomii politycznej siłom natury. Kapitałem, który miał wprawić w ruch tak konstruowany proces produkcji, były dla artysty studia, prace, utwory jego poprzedników. W rezultacie, opierając się na pracy artysty, powstawał produkt podlegający prawom ekonomicznym. Włodzimierz Spasowicz charakteryzując poglądy Proudhona stwierdził, że w wyniku takiej działalności „powstaje dzieło, które stanowi w ścisłym znaczeniu tego wyrazu własność pracownika, wszelako nie własność literacką, lecz taką samą, jak zboże albo len zebrany z pola przez rolnika lub jak zwierzyna, którą zastrzelił myśliwy"38.

Odpowiedź Włodzimierza Spasowicza na koncepcje francuskiego anarchisty zakładała, że prawa autorskie nie mogły być uznane za prawa rzeczowe, gdyż ich przedmiotem były utwory, a nie rzeczy. Z drugiej zaś strony istota praw autorskich, głównie ich bezwzględny charakter, wykluczał także możliwość jednoznacznego zakwalifikowania ich do kategorii praw umownych (zobowiązaniowych) ${ }^{39}$.

Refleksje petersburskiego adwokata przysięgłego poświęcone prawu autorskiemu oraz budowanej z wolna w XIX w. w Imperium Rosyjskim koncepcji ochrony własności literackiej, muzycznej i artystycznej, świadczą o uczestniczeniu prawników rosyjskich $\mathrm{w}$ wewnętrznym oraz międzynarodowym dyskursie

36 Konwencję podpisały, a następnie ratyfikowały następujące państwa: Belgia, Hiszpania, Francja, Niemcy, Szwajcaria, Tunezja (protektorat francuski), Wielka Brytania i Włochy. Zob.: J. Błeszyński, Konwencja berneńska a polskie prawo autorskie, Warszawa 1979, s. 15.

37 W. Spasowicz, O prawie własności w literaturze, [w:] Pisma, t. IV, Sankt Petersburg 1892, s. 105.

38 Cyt. za: ibidem, s. 21.

39 Idem, Prawa autorskie i kontrefakcja... , s. 25. 
na temat problematyki związanej z prawami twórców. Objęte analizą instytucje prawa autorskiego obowiązujące na gruncie rosyjskiego prawodawstwa przekonują, iż ochrona praw autorskich, pomimo dostrzeżonych przez Włodzimierza Spasowicza niedoskonałości i wad, stawała się podstawą, na której wpierać się miał przyszły rozwój rosyjskiej kultury. Autor doszukując się związków zachodzących pomiędzy kulturą duchową a kulturą prawną zaznaczył, że prawa autorskie jako materia prawodawcza stawały się ważniejsze „z dniem każdym, w miarę tego im większe postępy robi w Rosji literatura i sztuka"40.

\section{Bibliografia}

\section{Akty normatywne}

Vysoczajszie utvierżdiennyj 20 marta 1911 goda zakon' ob avtorskom' pravie, [w:] Svod Zakonov Rossijskoj Imperii, t. X, cz. I, Sankt Peterburg 1912.

\section{Czasopisma}

J., Uczta jubileuszowa, „Kraj” 16 maja (9 czerwca) 1899, nr 22.

„Kraj” 4(16) lipca 1882, nr 1.

Spasowicz W., Puszkin i Lermontow jako Bajroniści, „Ateneum” 1888, t. I, z. 3.

\section{Opracowania}

Bardach J., Spasowicz Włodzimierz, [w:] Polski Słownik Biograficzny, red. A. Romanowski, t. XLI/1, z. 168, Warszawa - Kraków 2002.

Bardach J., Włodzimierz Spasowicz (1829-1906), [w:] W obiektywie nauki i w lustrze pamięci (o uczonych, pisarzach i politykach XIX wieku), red. W. Sudnik, Warszawa 2004.

Błeszyński J., Konwencja berneńska a polskie prawo autorskie, Warszawa 1979.

Górnicki L., Rozwój idei praw autorskich: od starożytności do II wojny światowej, Wrocław 2013.

Jankowski M., Być liberałem w czasie trudnym. Rzecz o Włodzimierzu Spasowiczu, Łódź 1996.

Kmiecik Z., „Kraj” za czasów redaktorstwa Erazma Piltza, Warszawa 1969.

Kulczycka-Saloni J., Włodzimierz Spasowicz. Zarys monograficzny, Wrocław- Warszawa - Kraków - Gdańsk 1975.

Polska ustawa o prawie autorskim i Konwencja berneńska, red. F. Zoll, Warszawa 1926.

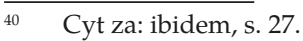


Prawo autorskie. Ustawa o prawie autorskim z r. 1926 w brzmieniu jednolitego tekstu z 1935 r. z objaśnieniami i dodaniem Konwencji berneńskiej, red. G. Groeger, Warszawa 1937.

Sławęcka E., Włodzimierz Spasowicz jako krytyk literatury rosyjskiej, Wrocław, Warszawa, Kraków 1969.

Spasowicz W., O prawie własności w literaturze, [w:] Pisma, t. IV, Sankt Petersburg 1892.

Spasowicz W., Prawa autorskie i kontrefakcja, Warszawa 1874.

Spasowicz W., Rzecz o tak zwanej własności literackiej, [w:] Pisma, t. IV, Sankt Petersburg 1892.

Szpoper D., Pomiędzy caratem a snem o Rzeczypospolitej. Myśl polityczna i działalność konserwatystów polskich w guberniach zachodnich Cesarstwa Rosyjskiego w latach 1855-11862, Gdańsk 2003.

Szpoper D., Wstęp, [w:] W. Spasowicz, Liberalizm i narodowość. Wybór pism, red. M. Jaskólski, J. Kloczkowski, M. Kuniński, R. Legutko, J. M. Majchrowski, T. Merta, B. Szlachta, Kraków 2010.

Zajączkowski W., Rosja i narody. Ósmy kontynent. Szkic dziejów Euroazji, Warszawa 2015. 